\title{
THE ROLE OF FAITH-BASED ORGANIZATION IN COPING WITH DISASTER MANAGEMENT AND MITIGATION Muhammadiyah's Experience
}

\author{
Zakiyuddin Baidhawy \\ IAIN Salatiga - Indonesia | zbaidhawy@gmail.com
}

\begin{abstract}
This study is aimed at exploring Muhammadiyah theological stand on disaster; its role and strategies in disaster management and mitigation. The ways in involving others and partnering with multiple stakeholders nationally and internationally also will be pictured. This study will show several things: First, Muhammadiyah perceives disaster in a positive way. As a consequence, it promotes awareness and on the importance of environment protection and management of risk and vulnerability. Second, Muhammadiyah establishes Muhammadiyah Disaster Management Center (MDMC) that focuses on organizing relief initiatives and disaster recovery which include mitigation and disaster anticipation trough Sekolah Siaga Bencana (Disaster-Prepared School) and Rumah Sakit Siaga Bencana (Disaster-Prepared Hospital). Third, Muhammadiyah works are guided by al-Ma'un theology and principles of universal humanism (al-nās), mutual recognition and understanding (ta'aruf), mutual assistance (ta'awun), and fulfilment of the rights of the survivors. Muhammadiyah works with various parties of communities at local, national, and international level. Muhammadiyah is able to escape missionary (dawa) trap and provide relief to all victims and survivors in a non-discriminatory manner.
\end{abstract}

Keywords: Disaster management, mitigation, faith based organization, Muhammadiyah.

\section{Introduction}

The magnitude of Mw 9.1-93 Indian Ocean earthquake on 26 of December 2004 was arguably the biggest natural disasters in Indonesia 
after Independence. It was followed by a Tsunami which destroyed miles of land and everything above it. It also has taken the life of almost 200,000 people.

This disaster has called many donor and international humanitarian agencies to provide relief programs, including those offered by faithbased organizations. The large scale of relief and assistance provided by faith-based organizations showed that religion and religious values remain relevant and important in the face of social reality and disaster. As a religious country, Indonesians value religion as fundamental aspect in building the character of the people and the nation. Interestingly, the religiosity also influences the ways in which people perceive disaster.

The experience of tsunami in Aceh 2004, as showed by Adiyoso and Kanegae ${ }^{1}$ has brought many programs developed by government, international organizations, and Civil Society Organizations. Unfortunately, little is known about the role of religious communities and faith based organizations in disaster management as well as in promoting the importance of preparation towards the disaster. Hence, this study finds its significance. Moreover, Indonesia has Muslims as the majority of the population. It also has numerous faith-based organizations where Muhammadiyah is one of the biggest Muslim Organizations. As organization working in the field of da'wah (Islamic propagation), education, health, and social charity, Muhammadiyah is called to contribute in addressing the issue of disaster in Indonesia. More specifically, Muhammadiyah insisted that religion must play the role in managing and mitigating disaster. In this regard, Muhammadiyah realizes that it is impossible to prevent disaster and therefore it is important to be able to address the issue properly. Moreover, disaster always comes with a great deal of lost both in material and lives. All these factors called Muhammadiyah to participate in raising the awareness of the people on disaster related matters as well as enabling them to mitigate disaster so that they can manage risk and lessen the number of victims and other losses.

This study focuses on the role of Muhammadiyah in dealing with disaster management in Indonesia; their strategies and also how they employ religious beliefs in their view towards the disaster but also at

\footnotetext{
1 Wignyo Adiyoso and Hidehiko Kanegae, "The preliminary study of the role of islamic teaching in the disaster risk reduction (a qualitative case study of Banda Aceh, Indonesia)," Procedia Environmental Sciences 17 (2013): pp. 918- 927.
} 
the same time detached their identity as religious-based organization in this issue which means that they did not push to have the preaching mission on the victims

\section{Religion, Disaster and Role of Faith Based Organizations}

In its development, the field of humanitarian issue and disaster risk management begun to take into account religious considerations. It is evident in the way scholars began to think about the role of Christian Church in the development in Africa and began to regard liberation theology as force of change. ${ }^{2}$ In December 2009, Center for Community Risk and Security at RMIT University organized a forum in the World's Parliament of Religions with the theme of Faith, Community and Disaster Risk Reduction'. Here, the speakers highlighted the importance of relation between religion and disaster. The importance lies on religious interpretation on disaster and the role of Faith-Based Organizations in disaster mitigation, anticipation, response, as well as post-disaster rehabilitation and reconstruction.

Western Paradigm about disaster places human beings dealing with the nature. Natural disasters like flood and fire are seen as dangers that must be conquered. In contrast, in the ancient spiritualism and many native traditions, human life is inseparable from nature. Instead of being perceived as "the act of God," natural disaster is regarded as consequence of destruction on nature by the hands of human beings. Here, the earth pays back human's carelessness, ignorance, and greed with floods and other disasters.

In line with that, we often find effective disaster mitigation strategies in the tradition of Native communities. Singas Village in Papua New Guinea for instance, is prone to flood. For generations, their houses were built on an assembly point above the hill to be used during the flood. Now, heavy rains and river flows can be monitored by advanced technology and can be informed to public through a good early warning system. The World perception in looking at water as primary source of life instead of hazards has equipped many people in the village with skill to mitigate disaster. ${ }^{3}$

2 Andreana Reale, "Acts of God(s): the role of religion in Disaster Risk Reduction," Humanitarian Exchange Magazine, 48 (October 2010), http://www.odihpn.org/humanitarian-exchange-magazine/issue-48/acts-of-gods-the-role-of-religion-in-disaster-riskreduction, accessed on 23 July 2015.

${ }^{3}$ J. Mercer and I. Kelman, "Living with Floods in Singas, Papua New Guinea," in Rajib Shaw, Noralene Uy and Jennifer Baumwool, Indigenous Knowledge for Disaster Risk 
Perception of religious leaders towards disaster is varied. Many of them perceive disaster as God's punishment, not as a mere natural phenomenon that is preventable by mitigation and anticipation. For example, in 2005, when earthquake struck Kashmir, several Muslim leaders interpret the calamities as God's punishment to the people. Similarly, Catholic and Evangelical leaders in Morolica, Honduras, also perceived hurricane as the Divine plan to chastise the people. ${ }^{4}$

A brief overview on religious thinking above underlines the importance to study religious views on disaster. Moreover, as Paulson and Menjivar pointed out, the study is very rare. ${ }^{5}$ Gaillard and Texier also said that scholarly studies on religion and disaster is still limited. Accordingly, they mentioned further that many religious studies also have not discussed the topic sufficiently.. ${ }^{6}$ Chester also shows that many theologians remain silent on the issue of natural disaster. ${ }^{7}$

As a result, the role of Faith-Based Organizations (FBO) in the context of development particularly in disaster management and mitigation is poorly acknowledged. ${ }^{8}$ Therefore, it is important to connect faiths and religious practices with its functions and dysfunctions in contributing or hindering someone to rise from disaster both socially and psychologically. With regards to the function of religion, several ideas worth mentioning are as follows:

First is the function of religion both at the time of disaster and at normal situation. It is quite common, religion plays quite a crucial role in providing psychological and social relief and assistance during the

Reduction: Good Practices and Lessons Learned from Experiences in the Asia-Pacific Region (UNISDR, 2008).

${ }^{4}$ M. Ensor, "Disaster Evangelism: Religion as a Catalyst for Change in Post-Mitch Honduras," International Journal of Mass Emergencies and Disasters, 21(2), 2003.

${ }^{5}$ N. Paulson, and C. Menjívar, "Religion, the State and Disaster Relief in the United States and India," International Journal of Sociology and Social Policy, vol. 32, no. 3 (2012): pp. 179-196.

${ }^{6}$ J. C. Gaillard, and P. Texier, "Religions, Natural Hazards, and Disasters: An Introduction," Religion, vol. 40, no. 2 (2010), pp. 81-4.

${ }^{7}$ D. K. Chester, “Theology and Disaster Studies: The Need for Dialogue," Journal of Volcanology and Geothermal Research, vol. 146, no. 4 (2005): pp. 319-328.

8 J. Berger, "Religious Nongovernmental Organizations: An Exploratory Analysis," Voluntas: International Journal of Voluntary and Nonprofit Organizations, vol. 14, no. 1 (2003): pp. 15-39. 
event of disaster. To give illustrations, people often found praying'9 and practicing rituals and ceremonies during and following the occurrence of disaster. This is exactly the time when faith-based organizations can play their role in psycho-social recovery. ${ }^{10}$ For individuals affected by disaster, religion can play internal (personal) roles or external (social) roles. Among internal functions are self-control, sense of purpose and hope, optimism and emotional consolation. Furthermore, religion can contribute actively in overcoming experience of disaster by reducing anxiety and assisting survivors to overcome their suffering and, at the same time, comfort the feelings of each other. ${ }^{11}$

In addition, religion can also be associated with several external functions such as access to social resources, opportunity for social involvement, and support to connect with and help others while building identity and positive sense of self. Members of religious groups can perform practical tasks during disaster. They can contribute in persons to help people affected by the disaster, provide shelter, food, water, and information on other aids. ${ }^{12}$

What is interesting in studying religion and disaster is the fact that religion is also connected to a number of dysfunction. Dysfunction of religion includes tendency to be fatalistic, pessimistic, subjective risk analysis, as well as dependency, and guilt. Levy, Slade and Ranasinghe conducted research among the Buddhist in Sri Lanka who were hit by tsunami in 2004 and discovered that fatalistic and pessimistic view among them relating disaster with karma. And, this tendency is closely related with deteriorating health in the first 6 months following the tsunami. ${ }^{13}$ Smith linked fatalistic religious views with low responsibility

${ }^{9}$ Gaillard and Texier, "Religions, Natural Hazards, pp. 81-4.

${ }^{10}$ B. Wisner, "Untapped Potential of the World's Religious Communities for Disaster Reduction in an Age of Accelerated Climate Change; an Epilogue \& Prologue," Religion, vol. 40, no. 2 (2010), pp. 128-131.

${ }^{11}$ B. Adeney-Risakotta, "Is There a Meaning in Natural Disasters? Constructions of Culture, Religion and Science," Exchange, 38 (2009): pp. 226-243.

${ }^{12}$ B. Adeney-Risakotta, "Is There a Meaning in Natural Disasters? Constructions of Culture, Religion and Science," Exchange, 38 (2009): pp. 226-243; Mohammad Rokib, "The Significant Role of Religious Group's Response to Natural Disaster in Indonesia: the Case of Santri Tanggap Bencana (Santana)," Indonesian Journal of Islam and Muslim Societies, vol. 2, no. 1 (June 2012): pp. 53-77.

${ }^{13}$ B.R. Levy, M.D. Slade, and P. Ranasinghe, "Causal Thinking after a Tsunami Wave: Karma Beliefs, Pessimistic Explanatory Style and Health among Sri Lankan Survivors," Journal of Religion and Health, 48, 1 (2009), pp. 38-45. 
in disaster response and disaster risk reduction. ${ }^{14}$ Meanwhile, Anderson and Woodrow stated that fatalistic religious view increase psychological and motivational vulnerability. ${ }^{15}$

In addition to fatalistic religious view, there are other ways in which religion hinders the psycho-social recovery post-disaster. When disaster is perceived as punishment from God, survivors develop guilt, rejection, and anger to God. Similarly, Clarke, Fanany, Kenny also mentioned that religion may hinder recovery, especially when it affirms that disaster is God's punishment and anger. ${ }^{16}$

The second issue relates to religious interpretation on religion and the connection between religion and disaster relief as well as religious recovery. This view suggests that men use religion to interpret disaster. In order for the victims to survive and revive, they need to understand what disaster is and attached meaning to the incidence. They utilize several religious interpretations to understand disaster. The attributive theodicy view remains the most common way in looking at disaster. Actual religious interpretation is always affected by cultural/local context. ${ }^{17}$

There are two examples of how society interprets disaster. In May 2006, earthquake struck Yogyakarta and Central Java provinces of Indonesia causing displacement of thousands of people. The community perceived disaster as the will of God and as punishment for rapid modernization committed by Sultan Hamengku Buwono, the king as well as governor of the province, and those of the community in general. They also believed that earthquake reflected the moral and cultural crisis caused by modernization. Modernization is perceived as

\footnotetext{
${ }^{14}$ K. Smith, "Risk Assessment and Management," in Environmental Hazards; Assessing Risk and Reducing Disaster, $4^{\text {th }}$ edition (London: Routledge, 2004), pp. 36-53.

15 M.B. Anderson, P. Woodrow, "A Framework for Analyzing Capacities and Vulnerabilities," in Rising from the Ashes, Development Strategies in Times of Disaster (Boulder and San Fancisco: Westview Press, 1989), pp. 9-25.

${ }_{16}$ M. Clarke, I. Fanany, and S. Kenny, Post-disaster Reconstruction: Lessons from Aceb (New York: Earthscan, 2010), p. 245.

${ }^{17}$ D. K. Chester, A.M. Duncan, and C.J.L. Dibben, "The Importance of Religion in Shaping Volcanic Risk Perception in Italy, with Special Reference to Vesuvius and Etna," Journal of Volcanology and Geothermal Research, 172, 3-4 (2008): pp. 216-228.
} 
secularization, materialism, moral decadence, and ecological exploitation. ${ }^{18}$

Similarly, eruption of Mount Merapi in 2006 drove the people of Yogyakarta and Central Java to seek for meaning in religion. They believe that the eruption was a threat. For them, the mountain is mystical and magical. People living around the mountain believe that in the crater of Mount Merapi exists a spiritual world as reflection of the material world (human life). The disturbance in the mountain also reflect disturbance in the human life. ${ }^{19}$ They also believe in performing ceremony of offering to ask the spirits living inside the mountain to protect the community from eruption.

In addition to how religion perceives disaster and its impact, the study also seeks to understand the role of local religious communities and Faith Based Organizations in pioneering disaster relief and disaster recovery. In the last few decades, the role of FBO in disaster relief and disaster recovery increases significantly. There are various FBOs involved actively in this activity; both in larger and smaller scale, along with their religious affiliation and focus.

Faith exposes its followers with a mandate to help others. "Love thy neighbor" is a golden rule of all religious traditions and motivates people of faith to care about the condition of others. Justice for the poor and the marginalized is the main teachings of Jewish holy book. The Bible also mandates assistance to the poor and the vulnerable in the society. ${ }^{20}$ Teachings on caring others also exist in Islam. This religion promotes the concept of zakät (alms-giving), infaq (support), and sadaqah (charity).

Here, Faith-Based Organizations have a long history of providing assistance to those in need. In the last decades, their activities increase in quantity and quality with regards to development, disaster relief and post disaster reconstruction. ${ }^{21}$ Unfortunately, for so many years, their

18 J. Schlehe, "Anthropology of Religion; Disasters and the Representations of Tradition and Modernity," Religion, 40, 2 (2010), pp. 112-120.

${ }^{19}$ M. R. Dove, "The Panoptic Gaze in a Non-western Setting; Self-surveillance on Merapi Volcano, Central Java," Religion, 40, 2 (2010), pp. 121-127.

${ }^{20}$ B. Adeney-Risakotta, "Is There a Meaning in Natural Disasters? Constructions of Culture, Religion and Science," Exchange, 38 (2009), pp. 226-243.

${ }^{21}$ J. Berger, "Religious Nongovernmental Organizations: An Exploratory Analysis," Voluntas: International Journal of Voluntary and Nonprofit Organizations, 14, 1 (2003), pp. 1539. 
efforts have been undermined and neglected by mainstream development agents. Orji mentioned that it is only recently that the FBOs are acknowledged as important players in humanitarian emergency both at national and international level. 22

Despite the fact that FBOs play important role in immediate and long-term response towards natural and man-made disasters, they received very little support and attention from the government and other disaster management agencies. Another consequence is that there are not many of them who integrate their formal disaster responses and anticipation activities with FBOs.

\section{Muhammadiyah's View on Disaster}

Muhammadiyah is a social-religious organization focusing on the importance of employing modern and rational understanding of Islam. This outlook also reflects its approach to various natural events by taking into account the teaching of Islam in the Qur'an and the Sunnah as main guidance. With regards to disaster, this organization looks at the incidence in two ways (figure 1 and figure 2). ${ }^{23}$ First, Muhammadiyah understands disaster as "calamities" or musibab which means test and tribulations from Allah. In this regard, there are two types of calamities/tests; good calamity (ḅasanah) and bad calamity (sayyi'ab). All forms of bad calamities may not be attributed to God because God is the Lord of Justice, Kindness, and Compassion. Bad calamity is not a form of anger and injustice, but a kindness and reflection of His compassion. Bad calamity can only be accredited to human behavior and their irresponsibility towards the nature.

Disaster or calamity whether in a form of natural disaster or manmade disaster is perceived by Muhammadiyah as destiny; something that has happened. Because it has happened, men do not have to curse or regret the incidence. Men need to accept the destiny and regard the incidence as means of reflection over their deeds; possible sins and "wrongdoings". Sin may be categorized into two; theological sin and

\footnotetext{
${ }^{22}$ N. Orji, "Faith-Based Aid to People Affected by Conflict," in Jos, "Nigeria: An Analysis of the Role of Christian and Muslim Organizations," Journal of Refugee Studies, 24, 3 (2011), pp. 473-492.

23 Majelis Tarjih dan Tajdid Pimpinan Pusat Muhammadiyah, Fikih Kebencanaan: Keputusan Musyawarah Nasional Tarjih ke-29 Tabun 2015 di Yogyakarta (Yogyakarta: Majelis Tarjih dan Tajdid PP Muhammadiyah, 2015), pp. 45-105.
} 
sociological sin. The former is caused by violation of God's order and the latter is caused by "miscalculation" in treating the universe.

Unavoidably, disaster or calamity brings direct and indirect impact to human life both individually and socially. Muhammadiyah believes that disaster or calamity brings two impacts. The negative impact ('usr) includes destruction, loss of life, displacement, stress, depression, and other fatalities. These impacts may not be avoided because the incidence had happened. Therefore, Muhammadiyah believes that men must be optimistic that there are lessons and learnings behind every disaster. Through optimism, disaster may reveal its positive impact (yusr) including the importance of proper planning and calculation in development; importance of wisdom in engaging with nature; and urgency in managing risks and vulnerabilities.

Figure 1. Meaning of Disaster

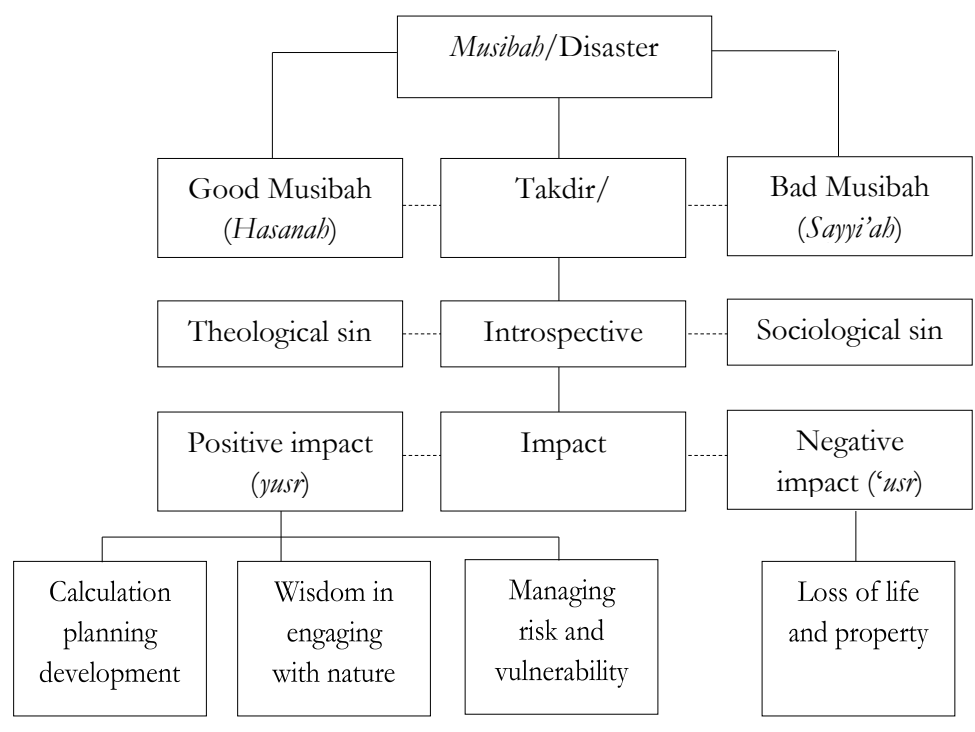

Muhammadiyah's view on disaster (explained above), borrowing Levy (et.al.), is a religious view that is certainly not fatalistic. ${ }^{24}$ Muhammadiyah does not believe that disaster is a destiny that must be

\footnotetext{
${ }^{24}$ B.R. Levy, M.D. Slade, and P. Ranasinghe, "Causal Thinking after a Tsunami Wave: Karma Beliefs, Pessimistic Explanatory Style and Health among Sri Lankan Survivors," Journal of Religion and Health, 48, 1 (2009), pp. 38-45.
} 
accepted with fatalistic attitude. In the fatalistic view, human being will easily deny their responsibility upon non-natural disaster (environmental and social disaster which, according to Muhammadiyah, is caused by human's action and human-driven environmental destruction. With realization that God is the Almighty, Muhammadiyah regards disaster as destiny that must be accepted and addressed with efforts to anticipate vulnerabilities and prevent future destruction.

Muhammadiyah looks at disaster with optimistic perspective. This is due to awareness that pessimism will only leave men devastated. Optimism encourages Muhammadiyah to response disaster or calamity in a positive way. Disaster happened is perceived as a medium of reflection on human's failures in sustaining the nature. Furthermore, it also motivates people particularly in Muhammadiyah to manage disaster along with the mitigation in a professional, well-organized and sustainable manner through Muhammadiyah Disaster Management Center (MDMC).

Muhammadiyah beliefs' is expected to prevent people from the trap of "dependency" and "guilt." Although Muhammadiyah does believe that the causes of disaster are theological and sociological sins, at the same time, however, Muhammadiyah refuses the idea that disaster is a form of God's anger and punishment towards sinners. Rather, in disasters lie lessons and learning's beneficial for the mind. In contrast, guilt can lead to inferiority and fatalistic attitude. With faith and optimism, human being can move from guilt to theological and sociological atonement. The theological remorse includes asking God for forgiveness upon individual sin and mistakes and sociological remorse means building new awareness on building harmony with the nature. The atonement will immediately be followed with initiatives to rise from devastation and not to develop dependency on aid and assistance.

Muhammadiyah also has a distinct point of view in interpreting disaster or calamity. Despite the believe that disaster happened is God's authority, Muhammadiyah believes that it is the human's responsibility to face the calamity in a proper and responsible manner. ${ }^{25}$ Here, the full responsibility (ra'iyyah) in facing calamity and its impact is actually the duty and authority of the government (whether central or local is dependant upon the scale and impact of

${ }^{25}$ Majelis Tarjih dan Tajdid Pimpinan Pusat Muhammadiyah, Fikih Kebencanaan, pp. 5565 . 
disaster). Government is an amir whose duty and responsibility is to care for its people. Therefore, government should claim the front row in responding disaster and providing post-disaster assistance. Others including $\mathrm{FBO}$ or people in general can participate but they do not hold the most influential role. In relation to that, Muhammadiyah also urges the importance of cooperation between all the parties; the government, the society, and/or community organizations, in addressing the issue.

More importantly, Muhammadiyah urges that all parties must uphold and implement four primary principles and they are awareness on universal humanity (al-nass), ta'aruf, ta'awn and the fulfillment of the victim's rights. The first principle means that disaster relief must be provided to everyone regardless of their sex, religion, social economic status, political affiliation, or other discriminating attributes. The second principle, ta'aruf, means that disaster relief must serve as a platform of collaboration between the people helping and the survivors. The third principle, ta'awn means mutual assistance between responders and people who are affected by disasters regardless of their identity. In other words, ta'aruf and ta'äwn are applied on the basis of universal humanity and are reciprocity. Responders and survivors may exchange position another time. The final principle is the fulfillment of the rights of the victims/survivors. This principle includes fulfillment of rights to mitigate disaster, manage vulnerability, and rights to relief, rehabilitation and reconstruction, and rights to implement disaster mitigation and disaster resiliency system. ${ }^{26}$

With regards to the principles for the victims, then they should face the calamity with gratitude and patience. The gratitude needs to be expressed verbally, by heart, and through action. Meanwhile, in the moment of negative calamity, they must verbally recite inna lillahi wa inna ilaybi rajiz 'un; accepting the calamity as a form of God's love for the human kind to fix their flaws and shortcomings; and change the negative situation into positive ones in the future. In conclusion, they must not fall into desperation upon negative calamity happening to them.

${ }^{26}$ Ibid., pp. 107-138. 
Figure 2. Responds to Disaster

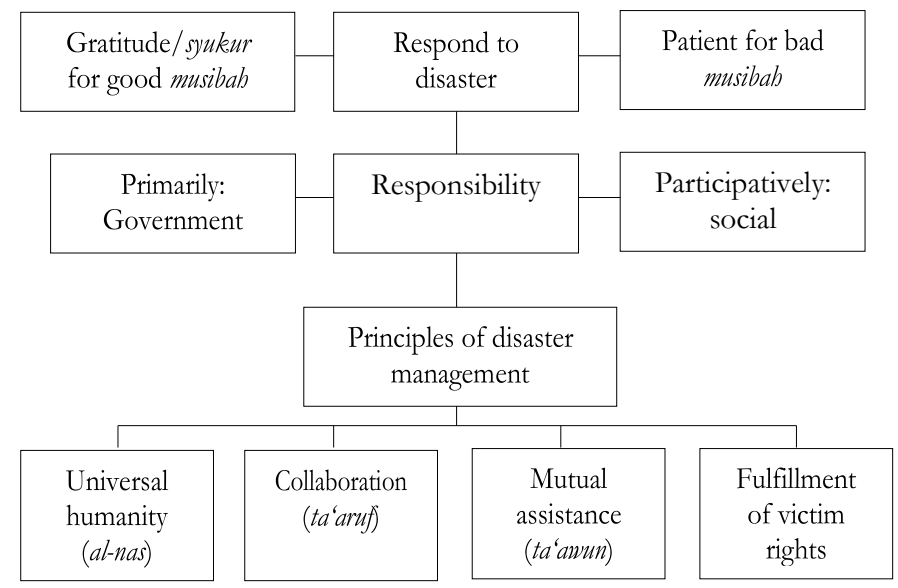

Perspective in interpreting and addressing disaster as shown by the theological understanding above is a reflection on how religion (read Islam), to borrow Wisner analysis, provides both internal and external functions. ${ }^{27}$ Muhammadiyah positively places Islamic teaching as a method to understand disaster and create meaningful life. Disaster makes patience and gratitude more meaningful; gratitude for those who survive and can take lessons from the disaster; patience for victims most affected by disaster. Patience is able to bring hope and optimism for the victims to survive and look into the future to prevent disaster from taking their self-control. Externally, Muhammadiyah disaster theology opens space for social participation in disaster relief effort. This theology motivates people to collaborate, volunteer, and build solidarity in helping the victims. People will not stand still in the face of others' suffering.

\section{Dakwah Kultural for Humanity}

As stated above, Muhammadiyah has a progressive theology in addressing disaster management and mitigation. Within this theological system, Muhammadiyah has built disaster management activities on the

${ }^{27}$ B. Wisner, "Untapped Potential of the World's Religious Communities for Disaster Reduction in an Age of Accelerated Climate Change; an Epilogue \& Prologue," Religion, vol. 40, no. 2 (2010), pp. 128-131. 
basis of universal humanity (al-nass). To be underlined, Muhammadiyah detached the preaching mission when doing their activities in disaster management. They do not intentionally invite or persuade people (red: victim) to join Muhammadiyah. They even do not invite non-Muslim converting to be Muslim. The emerging question is why does Muhammadiyah undergo this type of dakwah?

Muhammadiyah activity in disaster management and mitigation was started from the response of Aceh tsunami and earthquake in 2004. In regard of their identity as tajdid or renewal movement, Muhammadiyah has a vision that disaster issue can be a new focus for dakwah activity. This response is also supported by the spirit of "Dakwah Kultural" which is established two years before tsunami tragedy. Tanwir Council in Bali, on January 24th-27th 2002, has mandated the conceptual development of "Dakwah Kultural". Consequently, this concept has been legalized by Tanwir Council on June 26 $6^{\text {th }}-29^{\text {th }} 2003$ in Makassar.

Social and cultural dynamics, and the complex development of civilization demand Muslim endeavor and creativity in developing the main Islamic values as rạ̣matan li al-álamin. Dakwah Kultural is sustainable attempt of Muhammadiyah to accomplish Islam's mission as grace (rahmat) for the nature and universal humanity, both Muslim and non-Muslim (QS. Saba 34: 28). ${ }^{28}$

Muhammadiyah highlights three characters of Dakwah Kultural; dynamic, creative, and innovative. ${ }^{29}$ Dynamic means that Muhammadiyah needs to consider the dynamic of environmental, social, and cultural environmental changes. A series of disasters in this country enhances Muhammadiyah to give systematic response. Disaster should not be responded spontaneously and in sporadic way. Therefore, Muhammadiyah conducts an innovation in dakwah especially responding to answer the disaster challenge. In respect of this issue, Dakwah Kultural has challenged Muhammadiyah to plan a number of responding activities of disaster and mitigation which involves relief initiatives and post disaster recovery and its whole derivative activity.

Dakwah Kultural tends to impose the values of universal humanity. Their strategies has comprised "facilitating" (taysir) and "encouraging"

\footnotetext{
${ }_{28}$ Pimpinan Pusat Muhammadiyah, Dakwah Kultural Muhammadiyah (Yogyakarta: PP Muhammadiyah, 2003), p. 3.

${ }^{29}$ Ibid., p. 16.
} 
(tabsyir) approaches. ${ }^{30}$ The former approach means that dakwah kultural is aimed at alleviating or easing human burdens. In the context of disaster and mitigation, Muhammadiyah has emphatically attempted to ease up the burden of thesurvivors in the best way, both during the disaster and post disaster; preventive action to face the upcoming disaster. And the latter approach encourages Muhammadiyah in making endeavor to help the survivors overcoming their psychic trauma and economic problem. Muhammadiyah serves psychological counseling to reduce their psychic trauma and provides assistance to recover the economic condition by engagging them in training on micro and small scale of enterprises and life skill.

This dakwah kultural strategy help to relieve the survivors from their pain and confusion and support them to learn about love, affection and compassion (rahmah) in Islam. It is one of the goals of Muhammadiyah to promote the learning from all the interactions, relations, and sharings with others during the process to help them improve their awareness and skill in the ways to treat people with dignity.

Overreaching lack of the flexibility within the conventional dakwah, dakwah kultural is a new vision to objectify Islam's vision as rahmatan li al-álamin. Objectification is systematic effort to create Islamic values as shared ethics, without primordial claim, but focusing on the widespread of the values into life and be accepted as common benevolence. Kuntowijoyo has called this vision as humanization process. Humanization itself is a translation from amar ma'rüf. 31 Dakwah, appreciates social and multicultural aspect and developvarying cultural approaches and take the changing of place, time, and social need of the target in to the consideration. It can be said that dakwah kultural is an intervention strategyn to shift the paradigm from structural movement, which is absorbed by the country, to cultural movement respecting plurality of social and cultural life for a better life.

\footnotetext{
${ }^{30}$ Ibid., p. 13.

${ }^{31}$ See further Kuntowijoyo, Paradigma Islam: Interpretasi untuk. Aksi (Bandung: Mizan, 1991); see also Moeslim Abdurrahman, "BerIslam secara Kultural: Sebuah Pengantar," in Moeslim Abdurrahman (ed.), Mubammadiyah sebagai Tenda Kultural (Jakarta: Ideo Press and Maarif Institute for Culture and Humanity, 2003), p. xi.
} 


\section{Relief Initiative and Disaster Recovery}

Religious view on disaster, as described previously, is reflected in Muhammadiyah ways of responses towards disaster and in the ways in which they organize the efforts for relief. The reality of disaster related problems in this country along with its religious view encourages Muhammadiyah to establish Muhammadiyah Disaster Management Center (MDMC). The establishment of MDMC began in 2007 following Yogyakarta and Central Java earthquake. Before the establishment of MDMC, the Central Board of Muhammadiyah formed Muhammadiyah Committee for Aceh Recovery to provide relief for the victims of December 26, 2004 Tsunami. Starting from the 2010 Muktamar (General Assembly), MDMC was officially established as an institution responsible to organize Muhammadiyah resources in disaster response.

MDMC activities include mitigation, preparedness, emergency response and rehabilitation. MDMC adopts humanitarian volunteer Code of Conduct and other International charters. The institution develops their disaster risk reduction mission based on Hyogo Framework for Action and develops disaster preparedness in the community, at school, and at the hospitals as the basis of Muhammadiyah's movement since 100 years ago. ${ }^{32}$

MDMC works all across Republic of Indonesia wherever Muhammadiyah as organization operates. The institution works at the provincial and district/municipality level.

\section{Mitigation and Disaster Preparedness}

In promoting disaster mitigation and disaster preparedness, MDMC organizes Disaster Mitigation School or Sekolab Siaga Bencana (SSB) to enhance Muhammdiyah pioneering role in education. Since early $20^{\text {th }}$ century, Muhammadiyah has been pioneering education in Indonesia. The organization establishes tens of thousands of education institution including school, madrassa (Islamic school), pesantren (Islamic boarding school), and university, all across the country. Now, in response to the many disaster incidences in Indonesia, a country well-known as ring of fire, Muhammadiyah pioneered establishment of Disaster Mitigation School. This school serves as evidence that Muhammadiyah can move beyond its traditional boundaries as socialreligious organization. The effort to build Disaster School (SSB) does

32 http:/ / www.mdmc.or.id/index.php accessed on 1 July 2015. 
not only focus on Muhammadiyah schools consisting of Kindergarten, Elementary School, Junior High School, and High School, but also involves public and private schools in disaster prone areas.

At the moment, MDMC with LAZISMU (Lembaga Amil Zakat, Infaq, dan Sadaqah, Muhammadiyah Philanthropy Board) collaborate for Save Our School campaign by establishing pilot projects at one school in Kawasan Rawan Bencana (KRB, Disaster Prone Area) III at the slope of Mount Merapi and one school in East Java as an effort to build referral school for other schools in the area.

The initiative for this program began in 2007 through Child Disaster Awareness for School and Communities (CDASC) that has produced several tools available to download. One of the references produced is based on best practices extracted fromdisaster responses. The title of the manual is Mubammadiyah dan Kesiapsiagaan Bencana (Muhammadiyah and Disaster Preparedness). ${ }^{33}$ The manual serves as a reference for $\mathrm{Mu}-$ hammadiyah activists but it also can be used and referred to by others

The second program is establishment of Rumah Sakit Siaga Bencana (RSSB)/Disaster Preparedness Hopsital. The hospital program was built by MDMC in close coordination with Majelis Pembina Kesehatan Umum PP Muhammadiyah (Health Board of Muhammadiyah Head Office), Head Office of Aisyiyah and other related institutions working under Muhammadiyah. Hospital that is ready to tackle the impact of disaster will be referred to as Rumah Sakit Siaga Bencana (Disaster Preparedness Hospital). ${ }^{34}$

The program was initiated by Muhammadiyah in 2009 through Hospital and Community Preparedness for Disaster Management (HCPDM). It was implemented by Muhammadiyah Hospital Lamongan, Bantul, Palembang and Islamic Hospital Pondok Kopi Jakarta. In 2011, MDMC established similar program with the focus on disaster preparedness namely Rumah Komunitas Siaga Bencana (Disaster Preparedness Community House). Throughout a century of its establishment, Muhammadiyah has built 12,783 communities in the villages all across Indonesia along with women and youth organizations. MDMC perceived this social capital as strategic to

33 Barry Adhitya et.al., Mubammadiyah dan Kesiapsiagaan Bencana Jakarta: Risalah MDMC, 2009).

${ }^{34}$ http://www.mdmc.or.id/index.php accessed 1 July 2015. 
spread the message of Disaster Risk Management down to the level of communities in Indonesia.

MDMC promotes disaster preparedness based community development to follow up on Muhammadiyah programs that has begun 2006, with the concept of facilitation to post-disaster communities by the name of People Kampong Organized (PKO), Child Disaster Awareness for School and Communities (CDASC), Hospital and Communities Preparedness for Disaster Management (HCPDM) and Volcano Community-Hospital Ring (VaCHRi). These programs provided best practices for MDMC to initiates disaster preparedness community programs using the strength of the Muhammadiyah institutional networks.

\section{Disaster Emergency Response}

One of the mandates in the establishment of MDMC is to implement emergency response in their mission area in Indonesia. MDMC is obliged to mobilize Muhammdiyah resources both functional (members, hospital, university, and school) and network spread across 33 provinces, 429 districts, 3.366 sub districts, 12.783 communities/villages in Indonesia. Until 2014, Muhammadiyah has established MDMC in 20 provincial offices. In the meantime, MDMC at the level of district and municipality has only been established in Central Java, West Java, East Java, and Yogyakarta Special Region.

According to Rahmawati Hussein, although MDMC is only available at 20 provinces and districts/municipalities in Java, they still have the ability to provide assiatances to to other areas. As a matter of fact,the involvement and commitment of MDMC is appreciated bybeing awarded as "Most Active Community Organization in Disaster Response" in 2013 and 2014 from National Disaster Management Agency. ${ }^{35}$

Muhammadiyah volunteers for emergency response consist of the volunteers for Search and Rescue, Disaster Medic Committee (DMC), and Psychosocial and Community Development. Mobilization of volunteers continues and is organized trough coordination of Muhammadiyah stakeholders. They have been active in responding to various disasters in Indonesia such as Banjarnegara landslide 2006,

35 Rahmawati Husein, "Muhammadiyah dan Kemanusiaan: Kontribusi MDMC terhadap Penanggulangan Bencana Global," in Zakiyuddin Baidhawy et.al., Kiprah Pencerahan: Karya Unggulan Mubammadiyah 2005-2015 (Jakarta: CDCC, 2015), p. 214. 
Yogya earthquake 2006, Jakarta flood 2007, Bengawan Solo flood at the end of 2007 and beginning of 2008, Tasikmalaya earthquake 2009, and West Sumatera earthquake 2009. Although the organization was initiated in 2007, MDMC was not immediately able to organize and mobilize the volunteer well both in terms of capacity building and the management process. In addition to structural command of MDMC at the province and MDMC at the district/municipality, volunteer management also must pay attention to the existing basis of volunteers. Sober of this fact, MDMC focuses on integration of volunteers between 2010 and 2011.36

The volunteers can be categorized into four groups. First, medical volunteers work for the hospital and clinics under the coordination of Majelis Pembinaan Kesejabteraan Umat (Board of Health of Muhammadiyah). They work in 38 Muhammadiyah and Aisyiyah hospitals and are organized under Disaster Health Committee. They are also assisted by 5 Medical Assistance Team from Medical and Health Science Faculty of Muhammadiyah/Aisyiyah universities in Yogyakarta, Surakarta, Malang and Makassar. Second, psychosocial volunteers that are based in Faculty of Psychology at Muhammadiyah universities and therefore are organized under Majelis Pendidikan Tinggi dan Angkatan Muda Muhammadiyah (Muhammadiyah Board of Higher Education and Youth: Ikatan Pelajar Muhammadiyah, Ikatan Mahasiswa Muhammadiyah, Nasyiatul Aisyiyah). They work independently across Indonesia at almost all region affected by disaster with the support of Muhammadiyah Head Office and local offices. Third, environmental health volunteers that are based in Public Health Faculty at Muhammadiyah University. Trainings, curriculum development, and organization of health volunteers have been implemented by MDMC East Java with their hospital networks. Several hospitals that have been independently implementing this activity iare PKU Muhammadiyah Hospital Yogyakarta and Gombong, Islamic Hospital Pondok Kopi, Jakarta, and PKU Muhammadiyah Palembang. Fourth, SAR volunteers that are based in Komando Kesiapsiagaan Angkatan Muda Muhammadiyah (KOKAM)/Disaster Awareness Youth Force under coordination of Muhammadiyah Youth. Capacity and competence building for SAR team are developed independently by MDMC Central Java, Yogyakarta Special Region,

\footnotetext{
${ }^{36}$ Laporan Pelaksanaan Program Kerja Lembaga Penanggulangan Bencana Pimpinan Pusat Muhammadiyah 2010-2011.
} 
East Java, and South Sulawesi. In Central Java, distribution of SAR volunteers has reached $70 \%$ of the total districts in the province with Water and Mountain-Forest Search and Rescue competence. ${ }^{37}$

MDMC regularly organizes capacity building activities for disaster management. This activity is aimed at improving competence of people actively engaged in disastermanagement. Improvement of competence in disaster management within Muhammadiyah network leads to the trust building with other actors such local government.

\section{Post-Disaster Rehabilitation}

MDMC establishes post-disaster rehabilitation program to organize and institutionalize various initiatives related to disaster implemented by Muhammadiyah. At the national level, Muhammadiyah has completed post-Tsunami rehabilitation program in Aceh, post-earthquake in Yogyakarta in 2006 and West Sumatera in 2009 and post-Merapi eruption 2010.

These programs serve as the basis of experience and evaluation on management of post-disaster rehabilitation and reconstruction implemented by MDMC in the future. The focus of MDMC rehabilitation programs includes family economyic, clean water installations, temporary and permanent housing for vulnerable groups, rehabilitation of education facilities, healthcare facilities, as well as rehabilitation of environment and agriculture.

The following is a figure on how MDMC implemented rehabilitation of family economy post Merapi eruption in Yogyakarta Special Region. The eruption began on October 26, 2010 and destroyed many buildings and took hundreds of life. According to data from BNPB (National Disaster Management Agency), there were 309 people died and 467 people wounded. The total number of people living at 716 emergency shelters across the two provinces reached 202,483 people. In addition, the eruption also affected agriculture and the economy of the people living closest to the mountain. Therefore, MDMC, in collaboration with World Vision participated in helping the community recovering their livelihood affected by the eruption. ${ }^{38}$

\footnotetext{
${ }^{37}$ Husein, "Muhammadiyah dan Kemanusiaan, pp. 219-221.

38 Final Report on Muhammadiyah Disaster Management Center for World Vision Indonesia, Sistem Pemulihan Ekonomi Usaba Mikro Korban Erupsi Gunung Merapi DIYJateng, February 2011.
} 
Various efforts of post-disaster livelihood recovery have been implemented in the 5 areas including micro business development in fishery, animal husbandry, food processing, and mushroom breeding. Micro business in fishery involved 5 groups from Purwobinangun, Bangunkerto, Wonokerto, Polengan and Kradenan. The number of beneficiaries is 175 people consisting of 35 people from Purwobinangun, 30 people from Bangunkerto, 35 people from Wonokerto, 47 people from Polengan, and 37 people from Kradenan. The areas breed Catfish and Nila fish.

The livelihood recovery in agriculture involved two villages namely Purwobinagun and Kradenan. The initiative involved 67 beneficiaries; 35 farmers from Purwobinangun and 32 farmers from Kradenan. Activities developed by the group include polyculture and production of organic pesticide and fertilizer. Business development in animal husbandry engaged 73 farmers from two groups namely 35 beneficiaries from Bangunkerto and 38 beneficiaries from Purwobinangun. The group in Purwobinangun develop cow farming economic recovery and empowerment especially in food processing sectors involve women and mothers. The total number of beneficiaries is 206 people from four areas consisting of 70 direct beneficiaries from Purwobinangun, 45 from Bangunkerto, 41 from Polengan, and 50 from Kradenan. All four groups develop food products. For example, Purwobinangun and Bangunkerto develop Salak products including Salak sweets and chips, as well as banana products. In addition, they also produce traditional cakes to be sold at "Surya Merapi" gift store that was established on February 15, 2011. Meanwhile, Polengan and Kradenan develop products from Cassava that they named PATHILO (cassava snack/chips) and smoked catfish. Other small business developed is cultivation and production of mushrooms. Three villages participate in this program with a total number of beneficiaries is 123 people. 45 of them are coming from Wonokerto, 47 from Polengan, and 35 from Bangunkerto.

The economic rehabilitation program above is implemented simultaneously with provision of technical assistance on business development. The training does not only provides participant with theories but also practices to support them being ready to apply the skill in reality. The training was implemented based on the principle of adult education and is participatory. The training also provides insights 
on business analysis related to products that the participants are developing.

The training involves experts including Field Workers from Office of Agriculture, Animal Husbandry, and Fishery as well as mushrooms and fish business person. The training also invites expert from LIPI (Indonesia Institute of Science). Following the training, trainers/facilitators are responsible in providing follow up and further assistance including becoming consultant in implementation of activities.

Since micro business development initiated above will not be sustainable in the absence of market support, MDMC also provide market support. The strategy used in by connecting Muhammadiyah network from Central level to District/Municipality level and organizations working under Muhammadiyah to the micro business and connect to other relevant stakeholders. MDMC also facilitates joint marketing center in a form of show room in the district of Sleman and Magelang

With regards to capital needs, each area has established Financial Institution in a form of Koperasi Serba Usaha (Multiple Business Cooperative). In developing capital, the cooperative build agreement with Muhammadiyah through its Board of Community Empowerment and Board of Economy that will provide facilitation and support to the financial institution. The following is the list of cooperatives established and the beneficiary; Cooperative Surya Mitra Usaha in Purbowinangun, Cooperative Mitra Karya Mulia in Wonokerto, Cooperative Bangun Surya Mandiri in Bangunkerto, Cooperative Mandiri Makmur in Kradenan, and Cooperative Sinar Merapi in Polengan.

\section{Engagement and Collaboration with Local and International Communities}

Disaster management is a multidimensional and multi-stakeholder work. Therefore, Muhammadiyah believes the importance of collaborating with others/Muhammadiyah utilizes both internal and external networks. Internally, MDMC tries to collaborate with Lazismu (Muhammadiyah Philanthropy Board) to mobilize aid from the community to ensure the availability of fund for emergency response. The operational fund is also collected from hundreds Muhammadiyah hospitals, universities, and schools across Indonesia. Similar to what 
Leurs mentioned, ${ }^{39}$ independence in funding disaster response makes MDMC less reliant on the government and foreign donor. Eventhough the institution remains open to contribution from both entities, it only accepts the unconditional ones.

Participation of individual volunteers from internal network was also evident during eruption of Mount Merapi in 2010. MDMC with Muhammadiyah networks were able to mobilize at least 3,000 volunteers. The institution was also able to mobilize up to 2,500 volunteers during Mount Kelud eruption in 2014.

Externally, Muhammadiyah Disaster Management Center (MDMC) collaborates with local, national, and international institutions in disaster response activities. For example, MDMC develops synergy with the Badan Nasional Penanggulangan Bencana (BNPB, National Disaster Management Agency) and Badan Penanggulangan Bencana Daerah (BPBD, Regional Disaster Management Agency) at the Province and District/Municipality. These two agencies are mandated with disaster management based on Act No. 24, 2007. The synergy developed includes joint volunteers, socialization of Disaster Risk Reduction programs, Emergency Response and Rehabilitation programs, and community trainings.

Another cooperation of MDMC is with Ministry of Health along with its offices at province and city levels. They develop synergy in emergency response mission implemented by Disaster Medic Committee (DMC) and in Disaster Awareness Hospital programs.

In the context of collaboration with FBOs, Muhammadiyah is one of the members of Humanitarian Forum and it requires MDMC to be actively involved in the activities of Humanitarian Forum of Indonesia (HFI) along with Dompet Dhuafa, Karina, PPKM, World Vision, Yakkum Emergency Unit (YEU), YTBI, CWS, PKPU, and Habitat. In the issue of disaster education, MDMC is actively involved in one of the presidium on Consortium for Disaster Education which facilitates institutions including Government, NGO, and CSO working in mainstreaming Disaster Risk Reduction at schools. Meanwhile, in the issue of Disaster Risk Reduction, MDMC is active involved in various Disaster Risk Reduction platforms at national and local level.

In addition to participating actively in various forums above, MDMC also develops collaboration with various International

${ }^{39}$ R. Leurs, "Are Faith-based Organisations Distinctive? Comparing Religious and Secular NGOs in Nigeria," Development in Practice, 22, 5-6 (2012), p. 708. 
Organizations as a follow up of Muhammadiyah collaboration with these organizations during Aceh Tsunami 2004. The organizations collaborate with MDMC in various fields among them aer: 1) In Disaster Healthcare and Medical Service, MDMC collaborates with Direct Relief International, CRS, The Asia Foundation, JICA, Belgium, Mercy Relief, USAID, AUSAID; 2) In Post Disaster Education with WVI, AUSAID, Mercy Relief; 3) Children Center (Secured Area) with UNICEF, YOTS, and Save the Children; 4) Post Disaster Community Support and Building Place of Worship with WON Buddhism, TAF, United Arab Emirates, Kingdom of Saudi Arabia; 5) Trauma Counseling with Mercy Relief, Capacitas International; 6) Water Supply and Sanitation with AUSAID and IRD; 7) Emergency Logistic with Direct Relief International (DRI), Libya, IOM; 8) Livelihood with WVI, Give 2 Asia, AUSAID; 8) Women Program with UNIFEM, UNDP, Give 2 Asia; 9) School and Disaster Awareness Community with AUSAID; 10) Hospital preparedness with AUSAID, Direct Relief International; and 11) Capacity building with HOPE, US Pacific Command, ADPC, and ICRC.

Active involvement in developing networks with different organizations as described above shows that MDMC has earned, according to Leurs term, ${ }^{40}$ authority and trust from the locals. This leads MDMC as FBOs to earn bigger legitimation, authority, and trust from the members, domestic and international donor institutions, and the survivors/beneficiaries. It also shows that MDMC is capable of working beyond the exclusive boundaries of region, religion, race, ethnicity and community group. MDMC has become a part of international/global disaster response initiative through its involvement in disaster response in the Philippines for victims of Yolanda typhoon in 2013, and in providing humanitarian relief in Palestine, Syria, Myanmar, and Nepal. In terms of pioneering, MDMC participates and becomes active decision makers in the coordination forum between FBOs in Indonesia through Humanitarian Forum Indonesia.

One of the biggest factor and also distinguihig MDMC from other activities in Muhammadiyah is the fact that the entire operations of MDMC are based in the principle of universal humanities (alinsaaniyah). Based on this principle, MDMC works for everyone

${ }^{40}$ Ibid., p. 704-720. 
especially people affected by disaster regardless of their identity. MDMC will continue to uphold the Al Ma'un theology which shows care and compassion for all (rabmatan li al-älamin). Therefore, there is no doubt that although Muhammadiyah is a faith-based organization, their disaster response mission will never be aimed at spreading religion and trying to convert disaster survivor into Islam. Muhammadiyah remains true to the principle of tolerance and nondiscriminatory. MDMC also consistently upholds principle of neutrality and impartiality in their humanitarian mission.

\section{Conclusion}

As, a religious based organization, Muhammadiyah is guided by Islam and understandably has a preaching mission. Yet, there are differences between Muhammadiyah and the non religion-based NGOs in relation to disaster manegement. Muhammadiyah, as a faithbased organization is established with dakwah as the mission. However, with regards to disaster issue and problems, Muhammadiyah suceeds in escaping from the narrowed interpretation on what Dakwah is and how Dakwah should be conducted. Based on its belief in positive theology, Muhammadiyah perceive disaster positively, bearing in mind that all disaster is the will of God. The attitude toward disaster should be positive, not fatalistic. Positive attitude will rise victims from social and psychological impact of disaster and later move on towards reconstruction and psychological lift. Whereas the latter attitude will only leads to negative outlook on life and one's fate. Muhammadiyah established Muhammadiyah Disaster Management Center (MDMC) to provide reliefs and assistance for the victims of the disasters regardless their religious affiliation. It also opened schools and hospitals that prepare for disasters. [] 


\section{References}

\section{Books and Articles}

Abdurrahman, Moeslim (ed.). Muhammadiyah sebagai Tenda Kultural. Jakarta: Ideo Press dan Maarif Institute for Culture and Humanity, 2003.

Adeney-Risakotta, B. "Is There a Meaning in Natural Disasters? Constructions of Culture, Religion and Science." Exchange, 38 (2009): pp. 226-243.

Adhitya, B. et.al. Muhammadiyah dan Kesiapsiagaan Bencana. Jakarta: Risalah MDMC, 2009.

Adiyoso W. and Kanegae, H. "The preliminary study of the role of islamic teaching in the disaster risk reduction; a qualitative case study of Banda Aceh, Indonesia." Procedia Environmental Sciences 17 (2013): 918- 927.

Anderson, M.B., P. Woodrow. "A Framework for Analyzing Capacities and Vulnerabilities." in Rising from the Ashes, Development Strategies in Times of Disaster. Boulder and San Fancisco: Westview Press, 1989: 9-25.

Berger, J. "Religious Nongovernmental Organizations: An Exploratory Analysis." Voluntas: International Journal of Voluntary and Nonprofit Organizations. 14/1 (2003): 15-39.

Chester, D.K., AM. Duncan, and C.J.L. Dibben. "The Importance of Religion in Shaping Volcanic Risk Perception in Italy, with Special Reference to Vesuvius and Etna." Journal of Volcanology and Geothermal Research. 172/3-4 (2008): 216-228.

Chester, D. K. "Theology and Disaster Studies: The Need for Dialogue." Journal of Volcanology and Geothermal Research. vol. 146, no. 4 (2005): 319-328.

Clarke, M., I Fanany, S. Kenny. Post-disaster Reconstruction: Lessons from Aceh. New York: Earthscan, 2010.

Dove, M. R. "The Panoptic Gaze in a Non-western Setting; Selfsurveillance on Merapi Volcano, Central Java." Religion. 40/2 (2010): 121-127. 
Ensor, M. "Disaster Evangelism: Religion as a Catalyst for Change in Post-Mitch Honduras." International Journal of Mass Emergencies and Disasters. 21, 2 (2003).

Final Report on Muhammadiyah Disaster Management Center for World Vision Indonesia, Sistem Pemuliban Ekonomi Usaba Mikro Korban Erupsi Gunung Merapi Diy-Jateng, Februari 2011.

Gaillard, J. C., and P. Texier. "Religions, Natural Hazards, and Disasters: An Introduction." Religion. vol. 40, no. 2 (2010): 81 84.

Husein, R. "Muhammadiyah dan Kemanusiaan: Kontribusi MDMC terhadap Penanggulangan Bencana Global." in Zakiyuddin Baidhawy et.al. Kiprah Penceraban: Karya Unggulan Mubammadiyah 2005-2015. Jakarta: CDCC, 2015.

http://www.mdmc.or.id/index.php accessed on 1 Juli 2015.

Kuntowijoyo. Paradigma Islam: Interpretasi untuk. Aksi. Bandung: Mizan, 1991.

Laporan Pelaksanaan Program Kerja Lembaga Penanggulangan Bencana Pimpinan Pusat Muhammadiyah 2010-2011.

Leurs, R. "Are Faith-based Organisations Distinctive? Comparing Religious and Secular NGOs in Nigeria." Development in Practice. 22/5-6 (2012): 704-720.

Levy, B.R., M.D. Slade, P. Ranasinghe. "Causal Thinking after a Tsunami Wave: Karma Beliefs, Pessimistic Explanatory Style and Health among Sri Lankan Survivors." Journal of Religion and Health, 48, 1 (2009): 38-45.

Majelis Tarjih dan Tajdid Pimpinan Pusat Muhammadiyah. Fikih Kebencanaan: Keputusan Musyawarab Nasional Tarjib ke-29 Tabun 2015 di Yogyakarta. Yogyakarta: Majelis Tarjih dan Tajdid PP Muhammadiyah, 2015.

Mercer J., I. Kelman."Living with Floods in Singas, Papua New Guinea." in Rajib Shaw, Noralene Uy and Jennifer Baumwool. Indigenous Knowledge for Disaster Risk Reduction: Good Practices and Lessons Learned from Experiences in the Asia-Pacific Region. UNISDR, 2008. 
Orji, N. "Faith-Based Aid to People Affected by Conflict." in Jos. "Nigeria: An Analysis of the Role of Christian and Muslim Organizations." Journal of Refugee Studies. 24, 3 (2011): 473-492.

Paulson, N., C. Menjívar. "Religion, the State and Disaster Relief in the United States and India." International Journal of Sociology and Social Policy. vol. 32, no. 3 (2012): 179-196.

Pimpinan Pusat Muhammadiyah. Dakwah Kultural Muhammadiyah. Yogyakarta: PPM, 2003.

Reale, A., "Acts of God(s): the role of religion in Disaster Risk Reduction." Humanitarian Exchange Magazine. 48 (October 2010), http://www.odihpn.org/humanitarian-exchange-magazine/issue-48/acts-of-gods-the-role-of-religion-in-disaster-riskreduction, accessed on 23 July 2015.

Rokib, Mohammad. 'The Significant Role of Religious Group's Response to Natural Disasterin Indonesia: the Case of SantriTanggap Bencana(Santana)." Indonesian Journal of Islam and Muslim Societies. vol. 2, no. 1 (June 2012): 53-77.

Schlehe, J. "Anthropology of Religion; Disasters and the Representations of Tradition and Modernity." Religion, 40/2 (2010): 112-120.

Smith, K. "Risk Assessment and Management." in Environmental Hazards; Assessing Risk and Reducing Disaster. 4th edition. London: Routledge, 2004: 36-53.

Wisner, B. "Untapped Potential of the World's Religious Communities for Disaster Reduction in an Age of Accelerated Climate Change; an Epilogue \& Prologue.” Religion, vol. 40, no. 2 (2010): 128-131. 
Zakiyuddin Baidhawy

$194 \mid$ JOURNAL OF INDONESIAN ISLAM

VOLUME O9, NUMBER O2, DECEMBER 2015 